\title{
Population Dynamics of the Root-knot Nematodes Meloidogyne incognita (Kofoid \& White) Chitwood and M. javanica (Treub) Chitwood on Grapevines in two different Regions of South Africa. ${ }^{1}$
}

\author{
J.T. LOUBSER (a) and A.J. MEYER (b)
}

a. Viticultural and Oenological Research Institute, Private Bag X5026, 7600 Stellenbosch, Republic of South Africa.

b. Department of Entomology and Nematology, University of Stellenbosch, 7600 Stellenbosch, Republic of South Africa.

Submitted for publication: June 1987

Accepted for publication: September 1987

Keywords: Population dynamics, root-knot nematodes, Meloidogyne incognita, Meloidogyne javanica, grapevines.

\begin{abstract}
Two root-knot nematode species, Meloidogyne incognita and $M$. javanica, were studied with regard to their seasonal population fluctuations on grapevines growing in two vastly different climatic areas. Regular observations on reproduction and numbers of larvae in the soil were compared with patterns of root growth, soil temperature and moisture.

Population fluctuations of the two species showed similar trends in spite of the climatic differences in the two areas, but $M$. incognita in the northern Cape reached higher populations. Larvae populations in the soil declined in summer in both areas and increased during autumn to reach peaks in winter. With the onset of root growth in spring, larvae numbers decreased in the soil, as a result of large scale root penetration.
\end{abstract}

Present knowledge of root-knot nematode distribution in the root area of grapevines and the seasonal population fluctuations is largely inadequate. Root-knot nematode population dynamics is important because it forms the basis for advisory work about these nematodes. This lack of information may also have contributed to the unsatisfactory chemical control achieved in established vineyards in South Africa (Loubser \& De Klerk, 1986) as well as in other countries (Raski et al., 1981; Harris, 1986). No study has yet been made of the bionomics of Meloidogyne species in South African vineyards.

Temperature, humidity, light, aeration of the soil, age and nutritional status of the host may influence the biological activities in the life cycle and development of Meloidogyne spp. (De Guiran \& Ritter, 1979) while both the host plant and its environment will influence the population dynamics of these parasites (Ferris \& Van Gundy, 1979). Root-knot nematode populations are therefore thought to fluctuate between soil types, different hosts and different geographical locations. However, it was shown to follow the same pattern every year both on monocultured annuals (Johnson, Dowler \& Hauser, 1974) and perennial crops such as grapevines (Ferris \& McKenry, 1976a). Therefore, although soil temperature and soil moisture play an important role in nematode population numbers on grapevine as reported by Ferris \& McKenry (1974, 1976b), these may only be rate modifying factors which will not influence the nature of the annual population curve on a specific host plant.

The present study was carried out in order to learn more of the bionomics of Meloidogyne incognita and $M$. javanica on grapevines under two different climatic conditions in South Africa.

\section{MATERIALS AND METHODS}

\section{Experimental vineyards}

Two experimental plots were used: 1) A flood-irrigated vineyard on a loamy sand (Table 1) in the summer rainfall area (Vaalharts, Northern Cape Province) with a high infestation of Meloidogyne incognita. 2) A microjet-irrigated vineyard on sandy loam (Table 1) in the winter rainfall region (Bien Donné, Western Cape Province) infested with Meloidogyne javanica. Both vineyards were approximately 12 years old with Jacquez as rootstock.

TABLE 1

Soil characteristics of trial vineyards in Vaalharts and Bien Donné.

\begin{tabular}{|c|l|rcc|r|r|c|c|}
\hline $\begin{array}{c}\text { Depth } \\
(\mathrm{mm})\end{array}$ & Location & \multicolumn{3}{|c|}{ Sand (\%) } & $\begin{array}{c}\text { Silt } \\
(\%)\end{array}$ & $\begin{array}{c}\text { Clay } \\
(\%)\end{array}$ & $\begin{array}{c}\mathrm{pH} \\
(\mathrm{KC} 1)\end{array}$ & $\begin{array}{c}\mathrm{R} \\
(\mathrm{ohms})\end{array}$ \\
\hline 300 & Vaalharts & 73,9 & 17,0 & 1,0 & 1,1 & 7,0 & 5,7 & 1700 \\
& Bien Donné & 45,3 & 21,6 & 3,7 & 16,6 & 12,8 & 4,4 & 2900 \\
600 & Vaalharts & 74,3 & 16,1 & 0,9 & 0,8 & 7,9 & 5,6 & 1800 \\
& Bien Donné & 42,2 & 6,4 & 1,6 & 30,0 & 19,8 & 4,2 & 4400 \\
900 & Vaalharts & 71,4 & 16,3 & 0,9 & 1,2 & 10,2 & 5,4 & 2200 \\
& Bien Donné & 33,0 & 11,8 & 10,6 & 29,6 & 15,0 & 4,1 & 4500 \\
\hline
\end{tabular}

\section{Sampling procedures}

a. Soil: The Vaalharts vineyard consisted of four adjacent blocks of 25 vines each, planted in five rows (3,75 $\mathrm{m}$ apart) with five vines (1,5 $\mathrm{m}$ apart) per row. The experimental area for the Bien Donné vineyard consisted of ten rows of 40 vines each, with a vine spacing of $3,3 \mathrm{~m} \times 1,83 \mathrm{~m}$.

\footnotetext{
${ }^{\prime}$ Part of a thesis to be submitted by the senior author to the University of Stellenbosch for the Ph. D (Agric.) degree.
} 
An initial survey was conducted to determine the best sampling procedure for optimum nematode recovery in both plots because of the differences in layout. Based on these results, the four vineyard blocks of the Vaalharts vineyard were sampled separately, each by bulking 25 soil cores taken in the root zone $(10-450 \mathrm{~mm}$ depth) with a $25 \mathrm{~mm} \emptyset$ auger within $150-450 \mathrm{~mm}$ from the trunks of individual vines. The Bien Donné vineyard was sampled in the same manner but samples consisted of 40 soil cores each.

Because of the low number of vines in the Vaalharts trial and because sampling was performed on a weekly basis, soil cores had to be taken from the same vines every week. To avoid concentration of the root damage, consecutive samples were taken in a clockwise direction and towards the vine trunk after completing a full circle. At Bien Donné, sampling was done randomly every two weeks.

b. Roots: In order to establish periods of maximum nematode reproduction, root samples were collected weekly from four separate vines (one per block) and a $30 \mathrm{~g}$ aliquot was used for extracting eggs and larvae from each sample. This survey was conducted at Vaalharts only.

\section{Extraction procedures}

Samples were placed in plastic bags and processed 1-4 hours after collection. Analyses for second stage larvae in the soil were done by a motility-independent sieving-sedimentation method (Loubser, 1985) while root analyses for eggs and larvae were done according to the method of Hussey \& Barker (1973). For each egg suspension the embryonic development was recorded by distinguishing between undifferentiated eggs and eggs developed to the first larval stage. Second stage larvae in the egg sacs were also recorded.

\section{Root growth}

Root growth was measured only in the Vaalharts vineyard. This was done by means of underground observation chambers which allowed observation of four vines. Details of this study are discussed by Loubser \& Meyer (1986).

\section{Soil temperatures and soil moisture}

Soil temperatures were measured at $150 \mathrm{~mm}$, $300 \mathrm{~mm}$ and $600 \mathrm{~mm}$ depths on a three-hourly basis by means of soil thermistors coupled to a micrologger. Soil moisture was measured at $300 \mathrm{~mm}$ and $600 \mathrm{~mm}$ depth every second or third day by means of a mercury tensiometer. The average monthly soil temperature and soil moisture were calculated for both trial plots as well as the total monthly heat units (in degree days) as described by Tyler (1933).

\section{RESULTS AND DISCUSSION}

\section{Vaalharts trial}

Soil population fluctuations of Meloidogyne incogni$t a$ are shown as the average monthly number of secondstage larvae recorded (Fig. 1 A). Populations were low in summer (January), and apart from a drop during June, increased gradually to reach a peak in midwinter (July). Thereafter populations declined gradually to reach another low during summer the next season (December). Observations during the second year in the same vineyard confirmed these results. Similar results were obtained by Ferris \& McKenry (1974) in California.

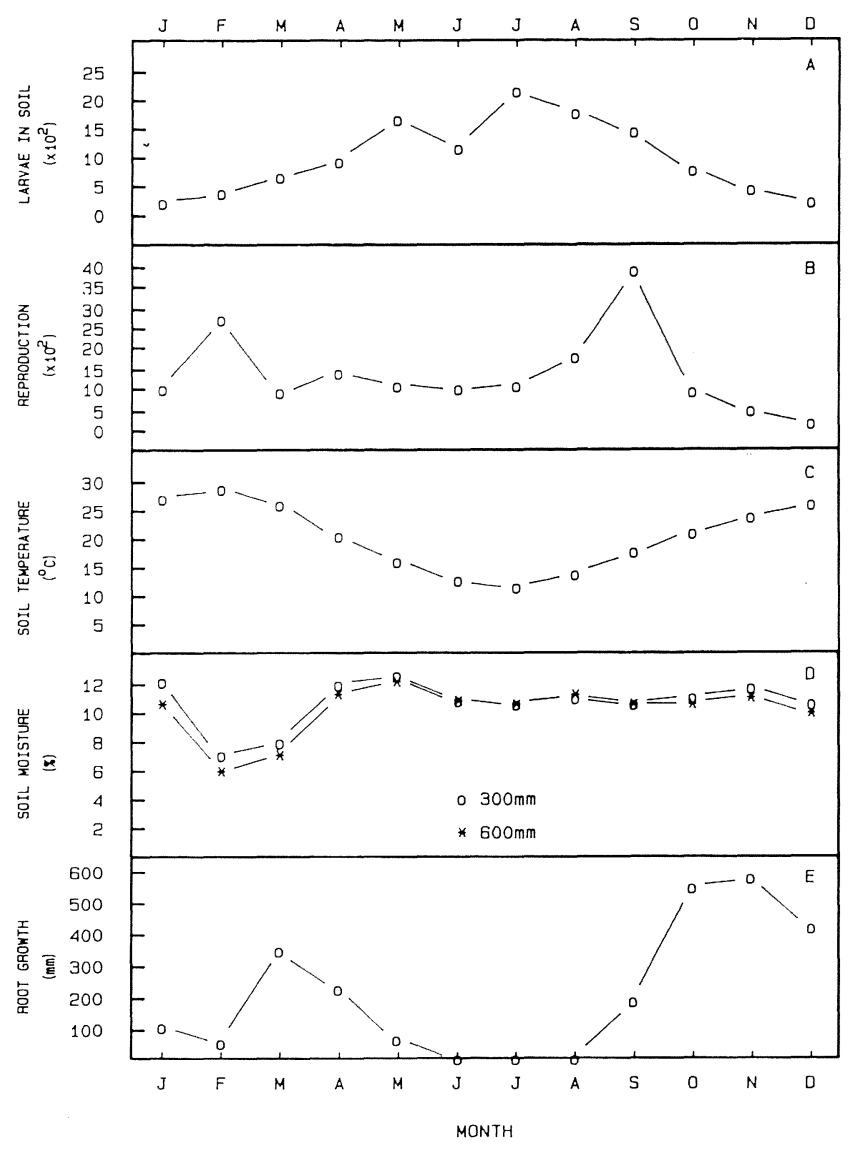

FIG. 1

Average monthly figures for number of Meloidogyne incognita larvae in the soil (A), reproduction as measured by eggs and larvae per $1 \mathrm{~g}$ of roots (B), soil temperature $(C)$, soil moisture (D) and root growth (E) of a vineyard at Vaalharts.

Soil temperatures at $150 \mathrm{~mm}, 300 \mathrm{~mm}$ and $600 \mathrm{~mm}$ differed very little and fluctuated slightly on a daily basis. For this reason only the average monthly temperature at $300 \mathrm{~mm}$ depth is shown in Fig. $1 \mathrm{C}$. Soil populations of the nematode reached a peak when soil temperatures were at their lowest $\left(12^{\circ} \mathrm{C}\right)$ and were low when soil temperatures were higher $\left(\max .29^{\circ} \mathrm{C}\right)$. During late winter most larvae were found in a coiled position, presumably responding to environmental stress (eg. low soil temperatures) by quiescence (De Guiran, 1979a).

The average monthly soil moisture levels at $300 \mathrm{~mm}$ and $600 \mathrm{~mm}$ depth are shown in Fig. 1 D. Soil moisture was relatively constant over most of the sampling period except for a steep drop during time of ripening of grapes (February and March). Soil larval populations were thus not markedly influenced by soil moisture.

The average monthly root growth is presented in Fig. $1 \mathrm{E}$. It shows a high number of new root tips in March and again during October, November and December. Very little root growth was recorded during June, July 
and August. At this stage larval populations in the soil were at their highest, probably because of the lack of available infestation sites and because of low activity due to low soil temperatures. The increase in numbers of larvae in the soil preceding this period can be explained by the decrease in new root growth as well as the reproduction of established females. At the onset of new root growth in spring (September), larval populations in the soil decreased rapidly to reach a low which persisted during summer.

According to Ferris \& McKenry (1974) root infestation in spring is primarily the result of newly hatched larvae because overwintering larvae appear to be of low infectivity. Although these larvae were found to be vacuolated as reported by the above workers, they only became so as soil temperatures increased during early spring and they became active. We believe that overwintering larvae constituted a high proportion of the invading population in the Vaalharts vineyards. Since the motility-independent extraction method which was used did not show a large number of dead larvae in the soil, these larvae must have penetrated newly developed roots.

Reproduction as expressed by the monthly average number of eggs and larvae extracted from roots, is shown in Fig. 1 B. The curve shows two definite peaks, one in late summer (February) and another during spring (September). Reproduction apparently fluctuated regardless of soil temperatures since both increases and decreases occurred with rising temperatures. On the other hand, nematode reproduction did remain relatively constant during winter, i.e. larvae and eggs were always present. The latter may represent eggs in diapause (De Guiran, 1979b) or quiescence (Linford, 1941). The fact that larval populations in the soil increased during winter, suggests, however, that reproduction or at least hatching continued throughout winter.

When reproduction is compared with soil moisture, no connection is found. A reproduction peak was observed during February when soil moisture was at its lowest and again during September when soil moisture was high. Soil moisture never dropped below 4-5\%, the level at which egg hatch is affected (Ferris \& McKenry, 1974).

It is known that soil temperature and soil moisture play an important role in the root-knot nematode's biology (Wallace, 1963). The effect they had on reproduction and development in this study was probably masked by the combined influence of all factors involved. Increasing soil moisture after harvest in March could have stimulated egg hatch and given rise to more second-stage larvae in the soil. This could have led to an increase in root infestation at a stage when new root growth occurred. The second reproduction peak in spring (September) was probably triggered by rising soil temperatures and coincided with another root growth flush.

Embryonic development and eclosion (i.e. the escape of the larvae through the egg shell) of root-knot nematode eggs in the Vaalharts vineyard, can be followed from the results listed in Table 2 . The percentage undifferentiated eggs, which may represent quiescence (Linford, 1941) or diapause (De Guiran, 1979b), did not increase during the observation period, suggesting that they did not occur. Wallace (1971) found in glasshouse experiments that eclosion, but not embryonic development, is arrested at low temperatures. This would have led to lower numbers of second stage larvae in the egg mass and a higher percentage of developed eggs during winter. At higher temperatures, on the other hand, embryonic development is inhibited (Wallace, 1971). The field results of the present study do not substantiate either of these two observations. The percentage of developed eggs decreased rather than increased during winter. This emphasizes the enormous gap between results sometimes obtained under controlled conditions and field trials.

TABLE 2

Seasonal egg development of Meloidogyne incognita on grapevine roots in Vaalharts vineyards.

\begin{tabular}{|l|c|c|c|}
\hline \multicolumn{1}{|c|}{ Month } & $\begin{array}{c}\text { Undifferentiated } \\
\text { eggs }\end{array}$ & $\begin{array}{c}\text { Developed } \\
\text { eggs } \\
\left(\mathrm{J}_{1} \text {-stage }\right)\end{array}$ & $\begin{array}{c}\text { Larvae } \\
\left(\mathrm{J}_{2} \text {-stage }\right)\end{array}$ \\
\hline January & 54 & 10 & 36 \\
February & 53 & 16 & 31 \\
March & 52 & 11 & 37 \\
April & 41 & 9 & 50 \\
May & 55 & 8 & 37 \\
June & 54 & 9 & 37 \\
July & 42 & 8 & 50 \\
August & 59 & 6 & 35 \\
September & 51 & 17 & 32 \\
October & 53 & 16 & 31 \\
November & 63 & 16 & 21 \\
December & 67 & 7 & 26 \\
\hline
\end{tabular}

1. Each developmental stage is expressed as a percentage of the total population extracted from $120 \mathrm{~g}$ roots $(4 \times 30 \mathrm{~g}$ replicates $)$.

\section{Bien Donné trial}

Fluctuations in numbers of Meloidogyne javanica larvae in the soil, soil temperature and soil moisture are shown in Fig. 2. Larval population trends are essentially similar to those of $M$. incognita in the Vaalharts trial with low numbers occurring in summer and high numbers occurring in winter. Much lower numbers of $M$. javanica larvae were present in the soil compared to the Vaalharts vineyard. This may be attributed to species differences, but ecological factors should also be considered.

Both surveys were conducted on Jacquez rootstock, but the soils involved were different (Table 1) and could have influenced nematode activities. Temperatures varied in a similar manner but with a mean minimum of $11^{\circ} \mathrm{C}$ in winter and a mean maximum of $22^{\circ} \mathrm{C}$ in summer. Soil moisture levels fluctuated between $7 \%$ and $14 \%$ as compared to $6 \%$ and $13 \%$ for the Vaalharts trial. Apart from a drop in soil moisture in May, the average soil moisture was ca. $11 \%$; almost the same as for the Vaalharts soil. According to Ferris, Schneider \& Semenoff (1984), temperature is the major extrinsic reproduction rate-determining factor and this is most probably responsible for the differences recorded between populations in the two vineyards. The number of degree days $\left(\mathrm{DD}_{10}\right)$ for both trials, are listed in Table 3 


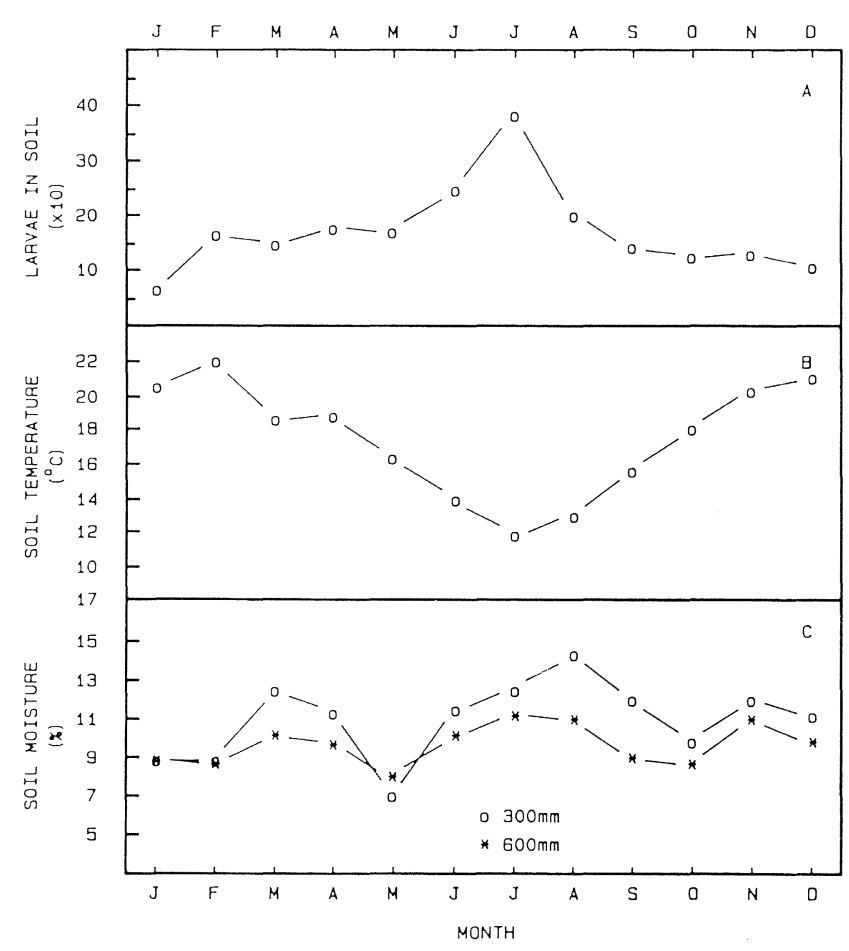

FIG. 2 .

Average monthly figures for number of Meloidogyne javanica larvae in the soil (A), soil temperature (B), and soil moisture $(\mathrm{C})$ in a vineyard at Bien Donné.

TABLE 3

Degree days $\left(10^{\circ} \mathrm{C}\right)$ calculated for trial vineyards at Vaalharts and Bien Donné.

\begin{tabular}{|l|c|c|}
\hline & \multicolumn{2}{|c|}{ Degree days $\left(\mathrm{DD}_{10}\right)$} \\
\hline \multicolumn{1}{|c|}{ Month } & Vaalharts & Bien Donné \\
\hline January & 588 & 376 \\
February & 510 & 326 \\
March & 567 & 330 \\
April & 316 & 183 \\
May & 263 & 249 \\
June & 115 & 135 \\
July & 78 & 84 \\
August & 151 & 121 \\
September & 218 & 159 \\
October & 399 & 273 \\
November & 386 & 280 \\
December & 445 & 314 \\
\hline Total: & 4036 & 2830 \\
\hline
\end{tabular}

for each month as well as accumulatively for the full sampling period.

Heat-units (Tyler, 1933) have been used to relate soil temperatures to Meloidogyne arenaria penetration and development in grapevines (Ferris \& Hunt, 1979; Ferris, Schneider \& Stuth, 1982; Ferris, Schneider \& Semenoff, 1984). The number of $\mathrm{DD}_{10}$ required by this nematode to reach maturity, differed between grapevine cultivars. From the results of Ferris \& Hunt (1979), $667 \mathrm{DD}_{10}$ was assumed to be neccessary for any Meloidogyne species to develop from the egg stage to maturity on a susceptible rootstock such as Jacquez. Based on this assumption, it was calculated that the number of root-knot nematode generations will be 6,05 and 4,24 per annum in the Vaalharts and Bien Donné vineyards respectively. These relative figures for numbers of generations in the two species examined may partially explain the differences recorded in nematode numbers in the different trial plots. It remains, however, necessary to investigate the reproductive potential of the two Meloidogyne species involved in more detail in order to determine its role in explaining population numbers.

\section{CONCLUSIONS}

In spite of differing climatic and other ecological conditions, $M$. incognita and $M$. javanica showed a cyclical fluctuation in numbers that was largely similar on the same host plant. The differences that were detected consisted merely of differences in the magnitude of the populations which was possibly the result of the greater number of generations on the site with the higher soil temperatures.

The results support findings by other workers with regard to seasonal fluctuations of root-knot nematodes. Although strongly affected by soil and climatic conditions, the population dynamics of obligate parasites such as root-knot nematodes, seems closely related to the host plant, especially with regard to root growth periods. This fact should be considered in any pest management programme in order to achieve improved nematode control.

Quiescence and diapause were not observed in the present study. They either did not occur in the vineyards under observation or the techniques used were not sensitive enough to detect them.

The information obtained in this study on the population dynamics of the two Meloidogyne species, coupled with our knowledge of grapevine root distribution and nematicide persistence in the soil, provides a solid theoretical basis for recommendations on rootknot nematode control. Appropriately, chemical control in established vineyards should commence immediately after harvest and/or during early spring. During these stages new root growth is initiated which should be protected against infestation by second stage larvae. However, the relative importance of infection of the two root growth flushes, is still unknown. Furthermore, importance of early applications, prior to infestation, should also be determined in order to establish the most effective time of application.

\section{LITERATURE CITED}

DE GUIRAN, G., 1979a. Survie des nématodes dans les sols secs et saturés d'eau: oeufs et larves de Meloidogyne incognita. Revue Nematol. 2, 65-77.

DE GUIRAN, G., 1979b. A necessary diapause in root-knot nematodes. Observations on its distribution and inheritance in Meloidogyne incognita. Revue Nematol. 2, 223-231.

DE GUIRAN, G. \& RITTER, M., 1979. Life cycle of Meloidogyne species and factors influencing their development. In: F. Lamberti and C.E. Taylor (eds.) Root-knot nematodes (Meloidogyne species); systematics. biology and control. Acad. Press, London, pp. 173-191.

FERRIS, H. \& HUNT, W.A., 1979. Quantitative aspects of the development of Meloidogyne arenaria larvae in grapevine varieties and rootstocks. J. Nematol. 11, 168-174. 
FERRIS, H. \& McKENRY, M., 1974. Seasonal fluctuations in the spatial distribution of nematode populations in a California vineyard. J. Nemol. 6, 203-210

FERRIS, H., \& McKENRY, M., 1976a. A survey of nematode distribution in California vineyard soils. J. Amer. Soc. Hort. Sci. 161, 332-336.

FERRIS, H. \& McKENRY, M., 1976b. Nematode community structure in a vineyard soil. J. Nematol. 8, 131-137.

FERRIS, H., SCHNEIDER, S.M. \& SEMENOFF, M.C., 1984. Distributed egg production functions for Meloidogyne arenaria in grape varieties and consideration of the mechanistic relationship between plant and parasite. J. Nematol. 16, 178-183.

FERRIS, H., SCHNEIDER, S.M. \& STUTH, M.C., 1982. Probability of penetration and infection by root-knot nematode, Meloidogyne arenaria, in grape cultivars. Am. J. Enol. Vitic. 33, 31-35.

FERRIS, H. \& VAN GUNDY, S.D., 1979. Meloidogyne ecology and host interrelationships. In: F. Lamberti and C.E. Taylor (eds.) Root-knot nematodes (Meloidogyne species); systematics, biology and control. Acad. Press, London, pp. 205-230.

HARRIS, A.R., 1986. Comparison of some nematicides on Vitis vinifera cv. Sultana in Victoria, Australia. Am. J. Enol. Vitic. 37, 224-227.

HUSSEY, R.S. \& BARKER, K.R., 1973. A comparison of methods of collecting inocula of Meloidogyne spp., including a new technique. Pl. Dis. Reptr 57, 1025-1028.
JOHNSON, A.W., DOWLER, C.C. \& HAUSER, E.W., 1974. Seasonal population dynamics of selected plant-parasitic nematodes on four monocultured crops. J. Nematol. 6, 187-190.

LINFORD, M.B., 1941. Some soil moisture relationships of the rootknot nematode. Phytopathology 31, 862.

LOUBSER, J.T., 1985. A modified sieving-sedimentation method for extracting nematodes from soil. Hort. Sci. 3, 23-25.

LOUBSER, J.T \& DE KLERK, C.A., 1986. Chemical control of root-knot nematodes in established vineyards, S. Afr. J. Enol. Vitic. 6, 31-33.

LOUBSER, J.T. \& MEYER, A.J., 1986. Strategies for chemical control of root-knot nematodes (Meloidogyne incognita) in established vineyards. S. Afr. J. Enol. Vitic. 7, 84-89.

RASKI, D.J., JONES, N.O., HAFEZ, S.L., KISSLER, J.J. \& LUVISKI, D.A., 1981. Systemic nematicides tested as alternatives to DBCP. California Agriculture, May-June, 11-12.

TYLER, J., 1933. Development of the root-knot nematode as affected by temperature. Hilgardia 7, 391-415.

WALLACE, H.R., 1963. The biology of plant parasitic nematodes. Edward Arnold (Publishers) Ltd., London.

WALLACE, H.R., 1971. The influence of temperature on the embryonic development and hatch in Meloidogyne javanica. Nematologica 17, 179-186. 